University of Pennsylvania Carey Law School

Penn Carey Law: Legal Scholarship Repository

Faculty Scholarship at Penn Carey Law

2020

\title{
Valuing the Freedom of Speech and the Freedom to Compete in Defenses to Trademark and Related Claims in the United States
}

Jennifer Rothman

University of Pennsylvania Carey Law School

Follow this and additional works at: https://scholarship.law.upenn.edu/faculty_scholarship

Part of the Comparative and Foreign Law Commons, First Amendment Commons, Intellectual Property Law Commons, Litigation Commons, Policy History, Theory, and Methods Commons, and the Public Policy Commons

\section{Repository Citation}

Rothman, Jennifer, "Valuing the Freedom of Speech and the Freedom to Compete in Defenses to Trademark and Related Claims in the United States" (2020). Faculty Scholarship at Penn Carey Law. 2394. https://scholarship.law.upenn.edu/faculty_scholarship/2394

This Book Chapter is brought to you for free and open access by Penn Carey Law: Legal Scholarship Repository. It has been accepted for inclusion in Faculty Scholarship at Penn Carey Law by an authorized administrator of Penn Carey Law: Legal Scholarship Repository. For more information, please contact PennlawIR@law.upenn.edu. 


\title{
Valuing the Freedom of Speech and the Freedom to Compete in Defenses to Trademark and Related Claims in the United States
}

\author{
Jennifer E. Rothman* \\ [forthcoming in HANDBOOK ON INTERNATIONAL AND COMPARATIVE TRADEMARK LAW \\ (Cambridge Univ. Press 2020) (eds. Jane Ginsburg \& Irene Calboli)] \\ (July 1, 2020 draft)
}

\section{Introduction}

Trademark and related unfair competition laws promote fair competition and protect goodwill but do not do so by providing broad monopoly rights. Instead, rights to a particular mark are limited to leave room for competitors, the dissemination of information, and the production of creative expression and commentary. This latitude is protected in part by limits on the scope of the rights afforded, but also by defenses to these claims. This Chapter primarily considers affirmative defenses to trademark infringement, trademark dilution, and false endorsement claims, focusing on defenses that serve the goals of free expression and fair competition. These free-speech based defenses should be of particular interest to comparative law scholars and non-U.S. practitioners because of their unique and elevated status in U.S. law. The First Amendment to the U.S. Constitution expressly prohibits Congress (and by extension states) from making or enforcing laws that "abridg[e] the freedom of speech.” This foundational aspect of U.S. law has influenced the development of and the interpretation of speech-based defenses to trademark and related claims. ${ }^{1}$

\footnotetext{
* (C) 2020 Jennifer E. Rothman. William G. Coskran Professor of Law, Loyola Law School, Loyola Marymount University, Los Angeles, CA.

${ }^{1}$ U.S. CONST. amend. I; see also Gitlow v. New York, 268 U.S. 652, 666-67 (1925) (noting the extension of the First Amendment to the states through the Fourteenth Amendment).
} 
Federal and state laws both provide trademark, unfair competition, and false endorsement laws, as well as defenses to those claims. This Chapter focuses on the federal regime under the Lanham Act, but the analysis here also applies to most state laws. $^{2}$ The Chapter covers the defenses of genericism, functionality, descriptive and nominative fair use, the Rogers test, statutory exemptions to dilution claims, and the questions of whether and how an independent First Amendment defense applies. The Chapter does not address other defense strategies, such as challenges to the validity of the underlying mark or to the likelihood of confusion (both parts of the prima facie case), even though they too are often guided by the values of promoting free speech and protecting the freedom to compete. $^{3}$

Before turning to the specifics of each defense, several overarching observations can be made about these speech and competition-related defenses. First, the speech or competition values asserted by the defendants influence the likely success of the claims. Defenses are more successful when the uses are in creative or artistic works, convey relevant information to potential consumers (even in advertising), or are deemed a commercial necessity.

A second and related observation is that the perceived "reasonableness" of the defendant's use will determine the likely success of the asserted defense. This is true even when the particular defense does not explicitly include such a consideration. Courts want to provide breathing room for expression, fair competition, and the provision of

\footnotetext{
${ }^{2}$ The governing federal Lanham Act is codified in 15 U.S.C. § 1051 (2012) et seq.

${ }^{3}$ The Chapter also does not consider affirmative defenses not rooted in free speech concerns, such as abandonment, misuse, antitrust violations, and various equitable defenses. See, e.g., Lanham Act § 33(b), 15 U.S.C. § 1115(b) (2012).
} 
information, but do not want to give refuge to those who are unreasonably exploiting and profiting from someone else's mark. This particular instinct likely explains courts' disfavoring of uses in merchandise.

Third, these defenses serve as a counterbalance to the broad scope of today's trademark law, which has expanded dramatically over the last century, particularly in the last few decades with the addition of dilution claims to the federal regime. Trademark law has moved away from a tort-based framework rooted in fraud and unfair competition claims, toward an intellectual property framework more similar to the monopolistic copyright and patent regimes with which it has long been contrasted. Originally, U.S. trademark law limited liability to instances in which there was likely confusion as to the origin of competing goods. Beginning in the late 1920s, it expanded to consider likely confusion as to related goods, then, in the 1960s, to consider potential (as well as actual) purchasers, and then once again, in the 1980s, to explicitly recognize confusion as to sponsorship and affiliation, as well as of origin. There can also be liability without regard to confusion, either under dilution laws (first added to federal law in 1996), or a misapplication of the initial interest confusion doctrine (that sometimes has allowed liability for simply attracting customers to a competing product or service without regard to likely confusion). Some of these expansions of the law are appropriate and uncontroversial, such as allowing claims based on consumer confusion as to sponsorship or in the context of related goods, but in combination these expansions mean that trademark law today can potentially limit far more speech than it used to. Accordingly, 
the speech-related defenses discussed in this Chapter provide increasingly important limits on trademark claims. ${ }^{4}$

\section{Genericism and Genericide}

As part of the prima facie case for trademark infringement or dilution, a plaintiff needs to establish that it has a source-identifying mark that is being used in commerce to distinguish its services or products. If the mark ceases to identify the source of the product or service and has instead become a generic name for that particular product, then courts will not provide trademark protection. Famous examples of what is sometimes described as “genericide” are “aspirin,” “yo-yo,” and “escalator,” which all began their lives as source-identifying trade names for these items, but over time became the terms used to refer to the products themselves, rather than to their source. ${ }^{5}$

The denial of trademark protection to generic terms is driven in part by the doctrinal requirement that trademark protection be granted only to words, designs, or symbols that serve a source-identifying function, something that generic words and

${ }^{4}$ See, e.g., Trademark Dilution Revision Act of 2006, Pub. L. No. 109-312, 120 Stat. 1730; Federal Trademark Dilution Act of 1995, Pub. L. No. 104-98, 109 Stat. 985, (1996); Trademark Law Revision Act of 1988, Pub. L. No. 100-667, 102 Stat. 3935, 3946 § 132, (1988); Pub. L. No. 87-772, 76 Stat. 769 (1962); Control Components, Inc. v. Valtek, Inc., 609 F.2d 763, 770 (5th Cir. 1980); Yale Elec. Corp. v. Robertson, 26 F.2d 972 (2d Cir. 1928); Aunt Jemima Mills Co. v. Rigney \& Co, 247 F. 407 (2d Cir. 1917); S. REP. No. 1333, at 3 (1946) (noting that "Trade-marks are not monopolistic grants like patents and copyrights) (citing Prestonettes v. Coty, 264 U.S. 359, 368 (1924) and United Drug Co. v. Theodore Rectanus Co., 284 U.S. 90, 97-98 (1918)). For critiques of some aspects of this trend see Jennifer E. Rothman, Initial Interest Confusion: Standing at the Crossroads of Trademark Law, 27 CARDOzO L. Rev. 105 (2005); Barton Beebe, The Semiotic Analysis of Trademark Law, 51 UCLA L. ReV. 621 (2004); Mark A. Lemley, The Modern Lanham Act and the Death of Common Sense, 108 YALE L.J. 1687 (1999); Jessica Litman, Breakfast with Batman: The Public Interest in the Advertising Age, 108 YALE L.J. 1717 (1999); Rochelle Cooper Dreyfuss, Expressive Genericity: Trademarks as Language in the Pepsi Generation, 65 Notre DAME L. ReV. 297 (1990).

${ }^{5}$ Bayer Co. v. United Drug Co., 272 F. 505 (S.D.N.Y. 1921); Donald F. Duncan, Inc. v. Royal Tops Mfg., 343 F.2d 655 (7th Cir. 1965); Haughton Elevator Company v. Seeberger (Otis Elevator Co.), 85 U.S.P.Q. 80 (Dec. Comm'r Pat. 1950). 
symbols cannot do. But the genericism doctrine also has an underlying speech-protective and competition-promoting impulse. Consumers and competitors need to be able to adequately describe their products in the marketplace. The defense of genericism arises when there are no equally good substitutes for the claimed mark to describe a particular product. In such circumstances, others need to be able to use the term to accurately convey information about what the product is-a First Amendment value, and also something necessary to compete in the marketplace. ${ }^{6}$

\section{A. The Right to Use a Term by Which a Product is Known}

The central concern for evaluating a genericism defense is whether taking a word out of circulation (at least in the context of a particular category of products) will prevent competition and obstruct the provision of information to the public. One of the bestknown cases to apply this doctrine is the 1938 U.S. Supreme Court decision in Kellogg Co. v. National Biscuit Co. ${ }^{7}$ This case involved an unfair competition claim brought by the National Biscuit Company against the Kellogg Company. National Biscuit objected to Kellogg calling its breakfast cereal "Shredded Wheat," and selling the cereal in a "pillow shape.” National Biscuit claimed to have trademarks in both the name and shape of shredded wheat (tracing back to the inventor of shredded wheat, Henry D. Perky). Perky had obtained utility patents for the process and machinery used to produce the "pillow-

${ }^{6}$ See Pierre N. Leval, Trademark: Champion of Free Speech, 27 Colum. J.L. \& ARTS 187, 189192 (2004); see also Cent. Hudson Gas \& Elec. Corp. v. Pub. Serv. Comm’n of New York, 447 U.S. 557, 562 (1980); Eugene Volokh, Speech as Conduct: Generally Applicable Laws, Illegal Courses of Conduct, "Situation-Altering Utterances," and the Uncharted Zones, 90 CoRnell L. Rev. 1277, 1304 (2005); cf. Thomas I. Emerson, Toward a General Theory of the First Amendment, 72 YALE L.J. 877, 878-79, 881-84 (1963) (the free speech values of truth-seeking, and informed decision making turn on the conveyance of information).

\footnotetext{
${ }^{7}$ Kellogg Co. v. Nat'l Biscuit Co., 305 U.S. 111 (1938).
} 
shaped” whole-wheat biscuits. There was also an issued design patent for the shape. All of the patents had expired by the time of Kellogg's use. ${ }^{8}$

The Supreme Court held that "Shredded Wheat" was a generic term, and therefore Kellogg could continue to use it for its own version of the breakfast cereal. The Court concluded that consumers understood "shredded wheat," to refer to the product itself, rather than to the source of the product. The Court highlighted that there was no other term that consumers or competitors could use to refer to the product. The public and competitors needed an equally good term to describe the particular product, and in the absence of one, the term "shredded wheat" could not be monopolized by National Biscuit. $^{9}$

\section{B. Overlapping Intellectual Property and the Public Domain}

The Kellogg case provides several other insights about defenses to trademarkbased claims. The case involved the interaction of trademark law with other IP laws, and the need to balance these overlapping laws to protect breathing room for invention, creativity, and communication. Although not a formal defense, courts resist (and for good reason) allowing trademark law to obstruct uses of works, inventions, or designs that were once protected by patent or copyright laws but have since entered the public domain. This issue arose in the Kellogg case because the shredded wheat patents had expired. The Supreme Court noted in its holding that "shredded wheat" was generic in part because the patent claims had not provided an alternative term for describing the invention. Accordingly, the name, as well as the invention, entered the public domain

\footnotetext{
${ }^{8}$ Id. at 113-20. The design patent had been invalidated prior to its expiration. Id. at 119 n.4.

${ }^{9}$ Id. at $116-17$.
} 
"upon the expiration of the patent." Trademark law could not take away with one hand what patent law had granted to the public domain with the other. ${ }^{10}$

\section{Toleration of Confusion and the "Reasonable Precaution" Standard}

The Kellogg decision highlights another issue in speech-related defenses to trademark claims-which is the need to tolerate some degree of likely consumer confusion as to source, sponsorship, or affiliation to provide room for the dissemination of information and creative expression. In the context of shredded wheat, the Court recognized that some confusion might occur if more than one company sold shredded wheat, particularly since the National Biscuit Company (and its predecessors) for many years had been the only seller of the product (given its patents on the process, machinery, and design). Nevertheless, the Court rejected National Biscuit’s contention that Kellogg had an obligation to remove "all possibility of deception or confusion." ${ }^{11}$ Instead, Kellogg only needed to act reasonably and fairly. It could use the term shredded wheat both as the name for the product and to describe it, as long as it took "reasonable precaution to prevent confusion or the practice of deception in the sale of its product.”12 Kellogg met this standard-the Court noted that there was no evidence that it tried to deceive consumers or pass off its product as that of National Biscuit's. ${ }^{13}$

${ }^{10}$ Id. at 117-18; cf. Dastar Corp. v. Twentieth Century Fox Film Corp., 539 U.S. 23 (2003) (limiting the application of the Lanham Act to a public domain work to avoid a "conflict with the law of copyright" and to prevent the creation of "a species of mutant copyright law that limits the public's federal right to copy and to use expired copyrights") (citations and internal quotations omitted).

${ }^{11}$ Kellogg Co., 305 U.S. at 121 (emphasis added).

${ }^{12}$ Id. at 122 (emphasis added).

${ }^{13} I d$. 
The Kellogg opinion highlights an important guiding principle that applies across trademark law's speech-related defenses-competitors are free to profit from goodwill created by others, as long as they do so reasonably and fairly. As the Court explained:

Kellogg Company is undoubtedly sharing in the goodwill of the article known as "Shredded Wheat"; and thus is sharing in a market which was created by the skill and judgment of plaintiff's predecessor and has been widely extended by vast expenditures in advertising persistently made. But that is not unfair. Sharing in the goodwill of an article unprotected by patent or trade-mark is the exercise of a right possessed by all-and in the free exercise of which the consuming public is deeply interested. $^{14}$

Even though there is no explicit requirement today that a defendant take "reasonable precautions" to dispel confusion, the analysis from Kellogg illuminates what remains true today-courts are heavily influenced by whether a defendant acted in good faith. When faced with potential confusion, defendants that make reasonable efforts to dispel such confusion will fare better. ${ }^{15}$

\section{Expressive Genericity}

In part because of the genericism doctrine's free speech motivations, some have advocated for a broadening out of the doctrine to cover expressive uses of marks that rely

\footnotetext{
${ }^{14} I d$.

${ }^{15}$ Cf. Barton Beebe, An Empirical Study of the Multifactor Tests for Trademark Infringement, 94 CALIF. L. REV. 1581, 1610, 1620-21, 1626-31 (2006) (“[A] finding of bad faith intent creates ... a nearly un-rebuttable presumption of a likelihood of confusion.”).
} 
on a mark's symbolic or cultural meaning, rather than on its source-identifying function. Most notably, Rochelle Dreyfuss in her influential 1990 article, Expressive Genericity: Trademarks as Language in the Pepsi Generation, contends that the defense of "genericity" should apply when a word or symbol is not substitutable, and is being used in an expressive context. Dreyfuss proposes that courts should

first decide whether there is an expressive component to the challenged use and then consider how central the trademark is to the usage. If the mark is found to be rhetorically unique within its context, it would be considered expressively-but not necessarily competitively-generic, and the trademark owner would not be permitted to suppress its utilization in that [expressive] context. ${ }^{16}$

Although courts have not explicitly adopted the proposed "expressive genericity" approach, they have incorporated its spirit in the context of other defenses (particularly nominative fair use analysis)—often allowing uses of marks in expressive works when the references are symbolic, rather than source-identifying. ${ }^{17}$

\section{Functionality}

The functionality defense serves similar goals to those of genericism. If the claimed product feature is functional in nature and the very reason a product works, it cannot be protected. One reason functional features are not protected is because they are not source-identifying-consumers will read the claimed feature not as telling them

\footnotetext{
${ }^{16}$ Dreyfuss, supra note 4, at 397, 418 \& passim.

${ }^{17}$ See discussion infra Section IV.B.
} 
whose product it is, but instead as an aspect of the product itself. The doctrine also ensures fair competition, and in some instances protects free speech. Monopolizing a particular product feature may lock others out of the marketplace, and unduly limit expression. ${ }^{18}$ The functionality defense often arises in the context of trade dress. Trade dress encompasses the design of a product, its packaging, and its overall image and appearance. $^{19}$

Courts have held that a product feature is functional under three circumstances: if the product feature is "essential to the use or purpose of the article"; if the feature "affects the cost or quality of the article"; or if the "exclusive use" of the feature would "put competitors at a significant non-reputation related disadvantage." ${ }^{20}$ In its 2001 decision in TrafFix Devices, Inc. v. Marketing Displays, Inc., the Supreme Court focused on the first of these inquiries-is the claimed feature essential to the use or purpose of the product? In TrafFix, the trade dress at issue was a dual-spring design for road signs. The claimed trade dress was the central subject of an expired utility patent, and the patent specifically included the dual-spring system in its claims as a mechanism to prevent the sign from blowing over in the wind. The plaintiff, Marketing Displays (MDI), identified no purely ornamental features as part of the claimed trade dress. Accordingly, the Court concluded

${ }^{18}$ Cf. Dan Burk, Patents and the First Amendment, 96 WASH. U.L. ReV. 197 (2018); Tun-Jen Chiang, Patents and Free Speech, 107 GEO. L.J. 309 (2019).

${ }^{19}$ In the context of unregistered trade dress, a plaintiff must establish (as part of the prima facie case) that the trade dress is not functional. In the context of registered trade dress, however, nonfunctionality is presumed, and a defendant has the burden to establish that a claimed feature is functional. Lanham Act §§ 2(e)(5), 33(b)(8), 43(a)(3), 15 U.S.C. §§ 1052(e)(5), 1115(b)(8), 1125(a)(3) (2012).

${ }^{20}$ TrafFix Devices, Inc. v. Mktg. Displays, Inc., 532 U.S. 23, 32 (2001) (quoting Qualitex Co. v. Jacobson Prod. Co., 514 U.S. 159, 165 (1995)); Inwood Labs., Inc. v. Ives Labs., Inc., 456 U.S. 844, 850 n.10 (1982). 
that the claimed design was functional and could not serve as a protectable mark. The design was the "reason the device work[ed]" - not a source-identifier. ${ }^{21}$

\section{A. Functionality and the Role of Alternative Designs}

The Supreme Court in TrafFix suggested that courts should not consider alternative designs when a product feature is "essential to the use or purpose of the article." ${ }^{22}$ In such instances, the feature is what makes the product work, and others are free to use that feature, even if there are other possible designs that could work as well for a similar cost. Most courts, however, even after TrafFix, continue to consider alternative designs. This is not surprising because in the absence of a particular feature being identified as functional in a utility patent, looking at alternative designs may be the best way to determine whether a feature is essential to the product's functioning. As the Ninth Circuit Court of Appeals has explained, "the existence of alternative designs cannot negate a trademark's functionality, but may indicate whether the trademark itself embodies functional or merely ornamental aspects of the product.”23

\section{B. Aesthetic Functionality}

${ }^{21}$ TrafFix Devices, 532 U.S. at 24, 29-30, 34-35.

${ }^{22} I d$. at 35 .

${ }^{23}$ Moldex-Metric, Inc. v. McKeon Prods., Inc., 891 F.3d 878, 884-85 (9th Cir. 2018) (quoting AuTomotive Gold, Inc. v. Volkswagen of Am., Inc., 457 F.3d 1062, 1072 n.8 (9th Cir. 2006)). Courts have adopted a variety of factors to evaluate functionality. See, e.g., Moldex-Metric, Inc., 891 F.3d at 880 n.2, 882. 
The third inquiry in functionality determinations turns not on whether a particular feature is essential for the product to work, nor on whether the feature affects the cost or quality of the product, but instead on whether the inability to use a particular feature would put competitors at a significant disadvantage in the marketplace for other reasons. This basis for finding a feature functional often arises in the context of aesthetic functionality-functionality derived from the appearance of a product. The Supreme Court has endorsed the doctrine of aesthetic functionality, and the notion that the appearance of a product can sometimes be essential to the appeal and usefulness of a product. $^{24}$

The doctrine of aesthetic functionality furthers consumers' interests in getting relevant and sometimes important information about products and services. Consider the use of blue for sleep aids. Blue is a color that signals nighttime and sleep, and is recognized as such by consumers, so the use of blue for sleep aids, like TYLENOL PM and UNISOM, is aesthetically functional-meaning that no one company can lock up the use of blue for this category of products. The use of similar shapes and colors may be especially important when it comes to generic versus brand-name versions of prescription medications. $^{25}$

The doctrine of aesthetic functionality sweeps more broadly than the appearance of prescription or over-the-counter medication. For example, the Seventh Circuit has held that the use of a circular shape for a beach towel is aesthetically functional, and a "basic

\footnotetext{
${ }^{24}$ Qualitex Co., 514 U.S. at 169-70.

${ }^{25}$ Inwood Labs, 456 U.S. at 861-62 (White, J., concurring); see also Qualitex Co., 514 U.S. at 165, 169-70; RESTATEMENT (THIRD) OF UNFAIR COMPETITION § 17, cmt. c (AM. LAW INST. 1995).
} 
design” that cannot be locked up by a single producer. ${ }^{26}$ The Eleventh Circuit has held that certain colors of ice cream are functional for particular ice cream flavors, such as pink for strawberry, white for vanilla, and brown for chocolate. ${ }^{27}$ And other courts have held functional the use of various colors in contexts in which the matching of colors is important, such as with furniture or farm equipment. ${ }^{28}$

In addition to promoting the dissemination of information and providing room for competition when consumers care about the appearance of products, the aesthetic functionality doctrine also provides room for expressive communication. For example, Christian Louboutin's eponymous company has claimed that it has a protectable mark in the color red when used on the soles of shoes. The company sued Yves Saint Laurent ("YSL”) for using red on the soles of some of its shoes. YSL claimed that using red on the soles of shoes is aesthetically functional. The district court agreed and suggested that the use of colors in the context of fashion is presumptively functional. ${ }^{29}$

On appeal, however, the Second Circuit rejected such a sweeping conclusion. The appellate court avoided deciding the question of aesthetic functionality by concluding that Christian Louboutin's red soles were not source-identifying in the context of an all-

${ }^{26}$ Jay Franco \& Sons, Inc. v. Franek, 615 F.3d 855, 860-61 (7th Cir. 2010).

${ }^{27}$ Dippin’ Dots, Inc. v. Frosty Bites Distrib., 369 F.3d 1197, 1202-1206, 1203 n.7, 1205 nn. 8-9 (11th Cir. 2004).

${ }^{28}$ See, e.g., Deere \& Co. v. Farmland, Inc., 560 F. Supp. 85, 98 (S.D. Iowa 1982), aff'd, 721 F.2d 253 (8th Cir. 1983).

${ }^{29}$ Christian Louboutin S.A. v. Yves Saint Laurent Am., Inc., 778 F. Supp. 2d 445, 449-50 (S.D.N.Y. 2011), aff'd in part, rev'd in part and remanded sub nom. Christian Louboutin S.A., v. Yves Saint Laurent Am. Holding, Inc., 696 F.3d 206 (2d Cir. 2012). 
red shoe-which is what YSL was selling-and therefore no claim could proceed. ${ }^{30}$ Despite the court's dodge of the aesthetic functionality question, there are good reasons why courts should consider the use of red soles on shoes as functional. Louboutin has said that he adopted the enameled red color for use on the soles because red is the color of attraction and sex, and using the color on the soles functions like a matador using a red cape to attract a bull (here the shoes are supposedly attracting potential mates). No other color can serve this function as well according to Louboutin. ${ }^{31}$ Nevertheless, not everyone agrees that the use is aesthetically functional. Some have suggested that because consumers now associate the red soles with Louboutin's shoes, his company should reap the rewards of that association. ${ }^{32}$

\section{Expressive Functionality?}

Jessica Litman has analogized the danger of locking up the symbolic meaning of marks to the dangers of locking up essential functional features of a product. She notes that "it has long been the rule that functional product features may not be protected, because they have too much value, not too little.”33 When the motivation for the

${ }^{30}$ Christian Louboutin S.A., v. Yves Saint Laurent Am. Holding, Inc., 696 F.3d 206, 228 (2d Cir. 2012). Litigation about the validity of Christian Louboutin's claimed mark in its red-soled shoes has spanned the globe. For a survey of some of the European decisions on the issue see Carina Gommers \& Eva De Pauw, 'Red Sole Diaries': A Tale on the Enforcement of Louboutin’s Position Mark, 11 J. INTELL. PROP. L \& PRAC. 258 (2016).

31 Louboutin's Hot High Heels (ABC television broadcast Nov. 18, 2011), https://abcnews.go.com/Nightline/video/louboutins-hot-high-heels-14987574.

32 See, e.g., Theodore C. Max, Coloring Outside the Lines in the Name of Aesthetic Functionality: Qualitex, Louboutin, and How the Second Circuit Saved Color Marks for Fashion, 102 TRADEMARK REP. 1081, 1094 (2012). For a detailed examination and critique of the current aesthetic functionality analysis see Justin Hughes, Cognitive and Aesthetic Functionality in Trademark Law, 36 CARDOZO L. REV. 1227 (2015); cf. Barton Beebe, Intellectual Property Law and the Sumptuary Code, 123 HARV. L. REV. 809 (2010) (discussing the communicative function of fashion).

${ }^{33}$ Litman, supra note 4, at 1728. 
defendant's use is based on conveying an expressive message, such as allegiance to or enthusiasm for a particular team, celebrity, or brand, some have suggested that a functionality defense is appropriate. Stacey Dogan and Mark Lemley contend that the functionality doctrine should protect uses of others' marks on merchandise, at least when there is no confusion as to official endorsement. ${ }^{34}$

The answer to whether aesthetic functionality (or other doctrines, such as fair use) should apply in the context of merchandise largely turns on the answer to the question of who should reap the rewards of what some describe as the "surplus value" of marks-the value that comes not from the source-identifying function of the mark, but from the cultural and expressive value of the mark. Markholders, whether the University of Kansas, the San Francisco Giants, Taylor Swift, or J. K. Rowling and Warner Brothers (with regard to the Harry Potter franchise), often contend that they should have the exclusive right to use their names, emblems, images, logos, and other symbols on merchandise even when consumers are not confused as to whether they are getting an official product from the sports team, recording artist, or author/film studio. So far, most courts have agreed with the markholders, no matter what defense is asserted, concluding that the markholders or celebrities should reap the value of the use of their marks or identities, even in the absence of confusion. ${ }^{35}$

34 Stacey L. Dogan \& Mark A. Lemley, The Merchandising Right: Fragile Theory or Fait Accompli?, 54 EMORY L.J. 461, 502-05 (2005); see also Savannah Coll. of Arts \& Design, Inc. v. Sportswear, 872 F. 3d 1256, 1260-67 (11th Cir. 2017).

${ }^{35}$ For a defense of such decisions, see Irene Calboli, The Case for a Limited Protection of Trademark Merchandising, 2011 U. ILL. L. REV. 865. For a recent critique of this trend see Madhavi Sunder, Intellectual Property in Experience, 117 MICH. L. REV. 197 (2018); see also Hughes, supra note 32, at 1230 (discussing shift to "valorization" of marks as "objects of value in and of themselves," rather than as source indicators). 
In the context of uses of marks on merchandise and clothing, most courts have therefore rejected functionality defenses. ${ }^{36}$ The Fifth Circuit, for example, rejected an aesthetic functionality defense in Boston Professional Hockey Association v. Dallas Cap \& Emblem Manufacturing. The court held that the Boston Bruins and other NHL teams could stop others from making and selling team emblems. ${ }^{37}$ The primary exception to this treatment is the Ninth Circuit's 1980 decision in International Order of Job's Daughters v. Lindeburg and Co. In that case, the International Order of Job’s Daughters, a young women's fraternal organization, sued a jewelry company for trademark infringement when it sold jewelry with the organization's insignia. The Ninth Circuit concluded that the uses by the defendant were aesthetically functional—used to signal support for the organization, rather than to indicate source or sponsorship. ${ }^{38}$

Despite the potential breadth of the analysis in Job's Daughters, other courts have not adopted such an approach, and the Ninth Circuit has limited the scope of the decision. In its 2006 decision Au-Tomotive Gold v. Volkswagen of America, the circuit rejected an aesthetic functionality defense when a defendant used Volkswagen's and Audi’s marks on key chains and license plate covers. The court concluded that in such an instance the "alleged aesthetic function is indistinguishable from and tied to the mark's sourceidentifying nature. . . . [C]onsumers want 'Audi' and 'Volkswagen' accessories, not beautiful accessories .... Any disadvantage Auto Gold claims in not being able to sell

\footnotetext{
${ }^{36}$ See, e.g., Bd. of Supervisors for Louisiana State Univ. Agric. \& Mech. Coll. v. Smack Apparel Co., 550 F.3d 465, 486-489 (5th Cir. 2008); Au-Tomotive Gold, Inc. v. Volkswagen of Am., Inc., 457 F.3d 1062, 1072-74 (9th Cir. 2006); Bos. Prof'l Hockey Ass'n. v. Dall. Cap \& Emblem Mfg., Inc., 510 F.2d 1004, 1013 (5th Cir. 1975).

${ }^{37}$ Bos. Prof'l Hockey Ass'n, 510 F.2d at 1013-14.

${ }^{38}$ Int'l Order of Job’s Daughters v. Lindeburg \& Co., 633 F.2d 912, 914, 918-20 (9th Cir. 1980).
} 
Volkswagen or Audi marked goods is tied to the reputation and association with Volkswagen and Audi." ${ }^{39}$ Accordingly, the defendant Auto-Gold was put at a reputationrelated disadvantage, rather than a non-reputation-related one. ${ }^{40}$

\section{Fair Use Defenses}

The fair use defenses to trademark claims provide room for businesses to compete in the marketplace, ensure that consumers get the information they need to make informed choices, and provide breathing room for free expression. Fair use in trademark law is substantively different from copyright's better-known fair use doctrine. Nevertheless, despite their doctrinal differences both share similar underlying motivations. Both are driven by a concern that if unbounded, these IP regimes could shut down important commentary and expression, and undermine the very basis for providing the IP protections in the first place. If trademark and related laws deny consumers useful information, and shut out legitimate competition, then they are working at cross-purposes with some of trademark law's intended objectives.

There are two distinct fair use defenses in the context of trademark law. The first is the defense of descriptive fair use-which focuses on the use of another's mark (or something similar) to describe qualities of a defendant's own product or services. This is sometimes referred to as "classic" fair use. The second type of fair use in trademark cases is nominative or referential fair use-which focuses on the use of another's mark to refer

\footnotetext{
${ }^{39}$ Au-Tomotive Gold, 457 F.3d at 1074; see also LTTB, LLC v. Redbubble, Inc., 385 F. Supp.3d 916, 921-2 (N.D. Cal. 2019) (citing Job's Daughters with approval and distinguishing Au-Tomotive Gold in context of witty pun printed on T-shirt), appeal docketed, No. 19-16464 (9th Cir. July 25, 2019).

${ }^{40}$ Id. at $1064,1073-74$.
} 
to and often comment on that mark (or associated product, service, or company). Each of these defenses will be considered in turn.

\section{A. Descriptive Fair Use}

Descriptive fair use has long been allowed by the common law, and now is also codified. Section 33(b)(4) of the Lanham Act provides a defense when the "use of the name, term, or device charged to be an infringement is a use, otherwise than as a mark," and the use is in a "descriptive" manner "fairly and in good faith only to describe the goods or services of such party, or their geographic origin." ${ }^{41}$ Descriptive fair use is also expressly provided as a defense to federal trademark dilution claims. ${ }^{42}$ To be considered a fair use, the use must be in "good faith,” and not to trade off the goodwill of a plaintiff's mark. Instead, the primary motive to use the particular term or symbol must be to accurately describe the defendant's own product or service. The defense applies only if the use is not as a mark for the defendant's products or services. ${ }^{43}$

One recent example of this defense is the Sixth Circuit's decision in Sazerac Brands v. Peristyle. The court allowed a competitor in the bourbon market to accurately refer to its plan to make bourbon at the famous Old Taylor Distillery in Kentucky, under the brand name CASTLE \& KEY. This use was allowed even though another company

${ }^{41}$ Lanham Act § 33(b)(4), 15 U.S.C. § 1115(b)(4) (2012) (emphasis added).

${ }^{42}$ Id. at $\S 43(\mathrm{c})(3)(\mathrm{A}), \S 1125(\mathrm{c})(3)(\mathrm{A})$. This provision was added as part of the Trademark Dilution Revision Act of 2006, Pub. L. No. 109-312, 120 Stat. 1730 (Oct. 6, 2005).

43 This longstanding defense and requirement that the use not be as a mark indicates that liability can exist for nontrademark uses of marks. In part because of this, as well as the argument's limited success in court, the possibility that a defense exists when a defendant does not use a plaintiff's mark as a mark for the defendant's own products or services is not addressed here. For those interested in this issue, compare Stacey L. Dogan \& Mark A. Lemley, Grounding Trademark Law Through Trademark Use, 92 IowA L. REV. 1669 (2007), with Graeme B. Dinwoodie \& Mark D. Janis, Confusion Over Use: Contextualism in Trademark Law, 92 IowA L. REV. 1597 (2007). 
sells bourbon under the label OLD TAYLOR and COLONEL E.H. TAYLOR. The use of the accurate geographic information about the location of the defendant's distillery could not be barred by the plaintiff despite its claim to the use of the Old Taylor name as a mark in the whiskey market. Free speech values and the promotion of fair competition both support the dissemination of this truthful and useful information to the public. ${ }^{44}$

Descriptive fair use is not limited to uses of geographic terms or product ingredients; it can also apply to descriptions of broader qualities or features of products. For example, in U.S. Shoe Corp. v. Brown Group, a court held that describing women's dress shoes as feeling like "sneakers" was a fair use. The case involved two competitors. Both companies touted the comfortable fit of their women's pumps. The plaintiff, U.S. Shoe, sold shoes under the brand name EASY SPIRIT. It claimed trademark protection for its ad slogan: “LOOKS LIKE A PUMP, FEELS LIKE A SNEAKER.” U.S. Shoe claimed that the defendant Brown Group’s use of phrases in its ad campaign referring to “sneakers" infringed its mark. Brown's advertisements for its pumps included the headline, “Think Of It As A Sneaker With No Strings Attached,” and the phrase, "when we say it feels like a sneaker, we're not just stringing you along." 45 In allowing the defendant's uses, the court explained the heart of the descriptive fair use defense:

A user of a descriptive word may acquire the exclusive right to use that descriptive word as an identifier of the product or source. This, however, does not justify barring others from using the words in good

${ }^{44}$ Sazerac Brands, LLC. v. Peristyle LLC, 892 F.3d 853, 855, 857-59 (6th Cir. 2018).

${ }^{45}$ U.S. Shoe Corp. v. Brown Grp., Inc., 740 F. Supp. 196, 196-197 (S.D.N.Y. 1990) (emphasis in original), aff'd, 923 F.2d 844 (2d Cir. 1990). 
faith for descriptive purposes pertinent to their products. . . The purpose of [the descriptive fair use] provision is to ensure that the according of monopoly trademark rights over descriptive marks . . . will not overbroadly deprive society of the use of those terms in their descriptive sense in commercial communication. ${ }^{46}$

Brown designed its pumps specifically to provide "the comfort of athletic shoes." The best way to inform consumers of that feature is to say that they feel like sneakers. The court therefore concluded that no company should be able to lock up the word "sneakers," or the useful information it conveys to consumers making selections in the marketplace. $^{47}$

Although descriptive fair use often arises in the context of word marks, it can apply to any type of mark. One court, for example, held that the use of a pine-tree shaped air freshener with a pine-tree scent was descriptive of the product. The plaintiff which sold all of its air fresheners (regardless of scent) in the shape of pine trees could therefore not stop others from using the shape of a pine tree when the scent of the freshener being sold was pine. The pine-tree shape signals to consumers the scent of the product—crucial information for their purchasing decision. ${ }^{48}$

Some confusion as to source or sponsorship must be tolerated in descriptive fair use cases. If this were not the case, the likelihood of confusion analysis would make the defense irrelevant. Nevertheless, several courts have suggested that there may be some

\footnotetext{
${ }^{46}$ Id. at $197-199$.

${ }^{47}$ Id. at $197-200$.

${ }^{48}$ Car-Freshner Corp. v. S.C. Johnson \& Son, Inc., 70 F.3d 267, 270 (2d Cir. 1995).
} 
tipping point at which confusion can defeat the defense. If a defendant intentionally misleads consumers, then it has acted in bad faith, and cannot benefit from the defense. Short of this, however, it is not clear when, or if, some high likelihood of confusion—or evidence of actual confusion by a substantial number of consumers-could defeat the defense even if a defendant acts in good faith.

There was hope that the Supreme Court might answer this question in its 2004 decision in KP Permanent Make-Up v. Lasting Impression. In that decision, the Court clarified that a defendant asserting a descriptive fair use defense does not have to establish the negative proposition that consumers are not likely to be confused. Instead, the plaintiff retains the burden to show a likelihood of confusion as part of the prima facie case. The Court noted that some level of confusion must be tolerated when a descriptive fair use has been made, but left open the question of whether there was some tipping point at which there was so much confusion that it could defeat the defense. ${ }^{49}$

Considering the case on remand, the Ninth Circuit concluded that "the degree of customer confusion remains a factor in evaluating fair use.” The court denied summary judgment to the defendant on its fair use defense for using the term "micro colors" in the context of permanent make-up. The appellate court instructed the jury to consider the fairness of the defendant's use, taking into consideration a number of factors, including the likely confusion caused by the use. ${ }^{50}$ Accordingly, there remains uncertainty about when likely (or actual) confusion can defeat a fair use defense.

${ }^{49}$ KP Permanent Make-Up, Inc. v Lasting Impression I, Inc., 543 U.S. 111, 121-24 (2004).

${ }^{50}$ KP Permanent Make-Up, Inc. v. Lasting Impression I, Inc., 408 F.3d 596, 609 (9th Cir. 2005); see also Marketquest Grp., Inc. v. BIC Corp., 862 F.3d 927, 935-38 (9th Cir. 2017) (emphasizing "that the degree of consumer confusion is a factor in the fair use analysis, not an element of fair use"), cert denied, 138 S. Ct. 1988 (2018). 


\section{B. Nominative or Referential Fair Use}

Trademarks and celebrities are part of our culture and therefore reference to them is often crucial for communication and artistic expression. To participate in the world around us we need to be able to refer to others' marks. These sorts of referential uses further fair competition, inform consumers, and promote the interests of free speech and free expression. Some courts have interpreted descriptive fair use to include references to another's products or services; for example, in comparative advertising, or to describe the content of expressive works that include marks, or a person's likeness or name. ${ }^{51}$ Many courts, however, evaluate these referential uses under a distinct fair use doctrine known as nominative fair use.

The nominative fair use defense is thought to originate with the Ninth Circuit's 1992 decision in New Kids on the Block v. News America Publishing. This case involved a lawsuit brought by the then hit boy band, New Kids on the Block. The New Kids objected to the use of their names and images by two newspapers that used them in the context of telephone-based polls that asked their readers to vote either for their favorite member of the band, or the sexiest. The newspapers advertised for the polls in their pages, and charged for the phone calls. Because the newspapers used the New Kid's mark to refer to the band, rather than to the papers' own products, the court concluded that the descriptive fair use defense did not apply. ${ }^{52}$

Nevertheless, the Ninth Circuit still held the use fair. The court emphasized the importance of being able to refer to another's mark for purposes of communication and

\footnotetext{
${ }^{51}$ See, e.g., ETW Corp. v. Jireh Publ'g, Inc., 332 F.3d 915, 918, 920-21 (6th Cir. 2003).

${ }^{52}$ New Kids on the Block v. News Am. Publ'g, 971 F.2d 302, 304, 308 (9th Cir. 1992).
} 
comparison. How could the papers conduct a poll about the New Kids without being able to refer to the band or its members? To establish the fairness of such referential uses the court held that a defendant must prove: (1) "the product or service in question must be one not readily identifiable without use of the trademark"; (2) "only so much of the mark or marks may be used as is reasonably necessary to identify the product or service"; and (3) the defendant "must do nothing ... [to] suggest sponsorship or endorsement by the trademark holder." ${ }^{\text {53 }}$ Applying these elements to the polls and announcements, the court held the newspapers' uses fair. The court rejected the New Kids' contention that only the band should profit from its fame: "trademark laws do not give the New Kids the right to channel their fans' enthusiasm (and dollars) only into items licensed or authorized by them." 54

Not all courts have agreed on this last point, even if they generally have welcomed and sometimes adopted the nominative fair use defense. In the context of merchandise, courts have been hesitant to extend the nominative fair use defense to uses of recording artists', celebrities', and sports teams' marks and identities on apparel, and other merchandise. Although nominative fair use often fails as a defense in merchandise cases, it has usually been successful in the context of uses in more traditional artistic works, or in accurate descriptions of the lawful sale or repair of products. The D.C. Circuit has described the "prototypical example of nominative fair use" as an automobile repair shop specializing in foreign vehicles run[ning] an advertisement using the trademarked names of various makes

\footnotetext{
${ }^{53} I d$. at 306, 308.

${ }^{54}$ Id. at 309 .
} 
and models to highlight the kind of cars it repairs. Permitting such use accommodates situations where it would be virtually impossible to refer to a particular product for purposes of comparison, criticism, point of reference or any other such purpose without using the mark. ${ }^{55}$

Many federal circuits (though not all) have embraced the nominative fair use doctrine. Congress also has endorsed the doctrine by explicitly including such a defense in the 2006 Trademark Dilution Revision Act. ${ }^{56}$ As with the descriptive fair use defense, there remains an open question of how much confusion will be tolerated. Part of the problem is the ambiguity contained within the third element of the nominative fair use defense-the one that requires that the user "do nothing that would, in conjunction with the mark, suggest sponsorship or endorsement by the trademark holder.” ${ }^{\text {}}$ Read one way, this could simply conflate with a likelihood of confusion analysis, but the doctrine makes sense only if interpreted to require some affirmative action to mislead or confuse consumers; otherwise, the likelihood of confusion analysis would be determinative and the defense irrelevant. ${ }^{58}$ Nevertheless, some courts have suggested that a showing of likely confusion defeats a nominative fair use defense. ${ }^{59}$

${ }^{55}$ Am. Soc'y for Testing and Materials v. Public.Resource.Org, Inc., 896 F.3d 437, 456 (D.C. Cir. 2018) (internal quotations and citations omitted); see also Toyota Motor Sales, U.S.A., Inc. v. Tabari, 610 F.3d 1171, 1175-83 (9th Cir. 2010).

56 Trademark Dilution Revision Act of 2006, Pub. L. No. 109-312, 120 Stat. 1730, 1730-32 (2006), codified at 15 U.S.C. § 1125(c)(3)(A) (2012).

${ }^{57}$ New Kids, 971 F.2d at 308.

${ }^{58}$ See Cairns v. Franklin Mint Co., 292 F.3d 1139, 1152-1156 (9th Cir. 2002).

${ }^{59}$ International Info. Sys. v. Security Univ., LLC, 823 F.3d 153, 165-69 (2d Cir. 2016). 
The second element of the defense is also sometimes challenging to determine. What is "reasonably necessary" to identify a product or service? Perhaps this inquiry is best understood as an evaluation of whether the use was unreasonably excessive in the context of an otherwise legitimate use. The Ninth Circuit, for example, rejected Terri Welles's nominative fair use defense on this basis. Welles, a former Playboy Playmate of the Year, was allowed to refer to Playboy and to having been the Playmate of the Year, but could not repeatedly and excessively use PMOY '81 (short for "Playmate of the Year 1981 ”) as the wallpaper/background for her website. ${ }^{60}$

\section{The Rogers Test and Uses in Expressive Works}

Some of the preceding defenses have been applied in the context of expressive works, but most often courts apply what is known as the Rogers test in such contexts. Courts have recognized that there are significant free speech concerns with using trademark and false endorsement laws to limit artistic expression, particularly in movies, songs, books, and other works of art. To address this concern the Second Circuit Court of Appeals developed what is known as the Rogers test, in which courts look at whether the allegedly infringing use is artistically relevant, and not explicitly misleading as to source or sponsorship.

The Second Circuit adopted this approach in Rogers v. Grimaldi, a case involving a claim that the movie title Fred \& Ginger constituted a false endorsement by famed

${ }^{60}$ Playboy Enters., Inc. v. Welles, 279 F.3d 796, 804-05 (9th Cir. 2002). 
screen star, Ginger Rogers. ${ }^{61}$ The movie was written and directed by acclaimed Italian director, Federico Fellini, and told the story of Italy’s “Fred and Ginger” (in reference to the Hollywood duo, Fred Astaire and Ginger Rogers). The court rejected Rogers's suit warning of the dire consequences if artistic expression could be limited by claims like hers. In doing so, the court set forth the analysis now known as the Rogers test:

[The Lanham Act] should be construed to apply to artistic works only where the public interest in avoiding consumer confusion outweighs the public interest in free expression. In the context of allegedly misleading titles using a celebrity's name, that balance will normally not support application of the Act unless the title has no artistic relevance to the underlying work whatsoever, or, if it has some artistic relevance, unless the title explicitly misleads as to the source or the content of the work. $^{62}$

The Rogers test has been widely adopted in the context of artistic works, and applied beyond uses in titles. The test is considered a First Amendment analysis, rather than a doctrine internal to trademark law. ${ }^{63}$ The Sixth Circuit applied the Rogers test as one of several bases for rejecting trademark and false endorsement claims brought by

${ }^{61}$ Rogers v. Grimaldi, 875 F.2d 994 (2d Cir. 1989).

${ }^{62}$ Id. at 999. In addition to her Lanham Act claims, Rogers brought state right of publicity and false light claims, which were also rejected by the court. Id. at 1002-05. In the context of false endorsement claims, state-based right of publicity claims can often be brought on the same set of facts. These right of publicity claims sometimes survive First Amendment review even when a Lanham Act claim does not. Compare In re NCAA Student-Athlete Name \& Likeness Licensing Litig., 724 F.3d 1268 (9th Cir. 2013), and Davis v. Elec. Arts Inc., 775 F.3d 1172 (9th Cir. 2015), with Brown v. Elec. Arts Inc., 724 F.3d 1235 (9th Cir. 2013); see also JenNifer E. Rothman, THE Right OF Publicity: Privacy ReIMAGined FOR A PUBLIC WORLD 157-59 (2018).

${ }^{63}$ Rogers, 875 F.2d at 997-1002. 
Tiger Woods arising out of the use of his name and image in an artist's painting (and prints) that showed Woods winning the Masters tournament. The court concluded that the uses of Woods's image and name were artistically relevant, and that the artist had done nothing affirmatively to suggest that Woods had endorsed or was affiliated with the work or its sale. ${ }^{64}$ The Rogers test has also insulated from liability uses of company names in video games and television shows, and of Mattel's Barbie dolls in various works of art. ${ }^{65}$

While the artistic relevance bar is supposed to be low, some courts have rejected uses as not sufficiently relevant. A recent Ninth Circuit decision, applying the Rogers test, concluded that uses of a social media sensation's catch phrases (such as "Honey Badger Don't Care”) on greeting cards was not artistically relevant under the Rogers analysis. The court so concluded because the defendant did not add its own artistic expression, but merely appropriated the goodwill of the plaintiff. ${ }^{66}$ More controversially, the Sixth Circuit held in Parks v. LaFace Records that the hip-hop group Outkast's use of "Rosa Parks" as the title for one of its songs was not artistically relevant as a matter of law, and that the case could proceed to trial on that issue. ${ }^{67}$ The court so concluded even though the song repeated the refrain "everybody move to the back of the bus," a clear reference to Parks, a civil rights icon who is best known for her refusal to move to the back of a segregated bus. The appellate court's questionable reversal highlights the

${ }^{64}$ ETW Corp. v. Jireh Publ'g, Inc., 332 F.3d 915, 937 (6th Cir. 2003).

${ }^{65}$ Twentieth Century Fox Television v. Empire Dist., Inc., 875 F.3d 1192, 1197-99 (9th Cir. 2017); E.S.S. Entm't 2000, Inc. v. Rock Star Videos, Inc., 547 F.3d 1095, 1100-01 (9th Cir. 2008); Mattel, Inc. v. Walking Mountain Prods., 353 F.3d 792, 807 (9th Cir. 2003); Mattel, Inc. v. MCA Records, Inc., 296 F.3d 894, 902 (9th Cir. 2002).

${ }^{66}$ Gordon v. Drape Creative, Inc., 897 F.3d 1184, 1195-96 (9th Cir. 2018).

${ }^{67}$ Parks v. LaFace Records, 329 F.3d 437, 442, 452-59 (6th Cir. 2003). 
challenge of determining what is artistically relevant. The district court in the case had concluded that the artistic relevance of Park to the song was patently "obvious.”68

While the Rogers test has often been a successful defense in the context of artistic works, it has fared less well when uses are in the context of merchandise. The Eleventh Circuit, for example, accepted the Rogers-test-based First Amendment defense in the context of paintings, prints, and calendars that used the University of Alabama's uniforms, but declined to apply the defense in the context of "mugs and other 'mundane products," such as flags, towels, and t-shirts-even though the same images appeared in both the artistic works and the "mundane products." Although the court concluded that the appellant, New Life Art, did not preserve the First Amendment and fair use defenses in the context of the mundane products, the court's division of the categories and differential treatment was not required, and the court left in place the district court's rejection of those defenses in the context of uses on merchandise (with the exception of the uses on calendars). ${ }^{69}$

Although the Rogers test has been widely adopted, at least some courts and scholars contend that the test is largely superfluous because the Lanham Act should not apply to most uses in expressive works other than advertising for such works. This view rests on the contention that the Lanham Act applies only to commercial speech (loosely defined either as commercial advertising or other speech directed primarily at selling

${ }^{68}$ Parks v. LaFace Records, 76 F. Supp. 2d 775, 780 (E.D. Mich. 1999), aff'd in part, rev'd in part and remanded, 329 F.3d 437 (6th Cir. 2003); see also RothMAN, supra note 62, at 149-51.

${ }^{69}$ Univ. of Alabama Bd. of Trustees v. New Life Art, Inc., 683 F.3d 1266, 1278-80 (11th Cir. 2012); Univ. of Alabama Bd. of Trustees v. New Life Art, Inc., 677 F. Supp. 2d 1238, 1250-51, 1258-59 (N.D. Ala. 2009); cf. RothmAN, supra note 62, at 170-75 (discussing the different treatment of merchandise in right of publicity cases). 
products or services). ${ }^{70}$ Many courts, however, have concluded (or presumed) that the Lanham Act does apply to noncommercial speech, including to expressive works. ${ }^{71}$ As I discussed in Commercial Speech, Commercial Use, and the Intellectual Property Quagmire, this is a reasonable reading of the statute, and supported by the policy behind the legislation. ${ }^{72}$ As the Second Circuit in Rogers explains:

Movies, plays, books, and songs are all indisputably works of artistic expression and deserve protection. Nonetheless, they are also sold in the commercial marketplace like other more utilitarian products making the danger of consumer deception a legitimate concern that warrants some government regulation. Poetic license is not without limits. The purchaser of a book, like the purchaser of a can of peas, has a right to not be mislead as to the source of the product. ${ }^{73}$

If the Lanham Act applies to expressive works, which it likely does, liability should nevertheless be rare when the uses are in the body of these works, rather than in the titles or advertisements for those works. Uses within the expressive works themselves

70 See, e.g., Farah v. Esquire Magazine, 736 F.3d 528, 541 (D.C. Cir. 2013); Taubman Co. v. Webfeats, 319 F.3d 770, 774 (6th Cir. 2003); Rebecca Tushnet, Trademark Law as Commercial Speech Regulation, 58 S.C. L. REV. 737, 738-39 (2007). I discuss the widespread confusion and disagreement among the courts about these issues in Jennifer E. Rothman, Commercial Speech, Commercial Use, and the Intellectual Property Quagmire, 101 VA. L. REV. 1929 (2015); see also Lisa P. Ramsey, Increasing First Amendment Scrutiny of Trademark Law, 61 SMU L. REV. 381, 403-04 (2008).

${ }^{71}$ See, e.g., Westchester Media v. PRL USA Holdings, Inc., 214 F.3d 658, 672 (5th Cir. 2000); Dr. Seuss Enterprises, L.P. v. Penguin Books USA, Inc., 109 F.3d 1394, 1403-07 (9th Cir. 1997); AnheuserBusch, Inc. v. Balducci Publ'ns, 28 F.3d 769, 776-78 (8th Cir. 1994); Browne v. McCain, 611 F. Supp.2d 1073, 1079 (C.D. Cal. 2009). For more examples, see Rothman, supra note 70, at $1937-46$ \& accompanying notes.

${ }^{72}$ Rothman, supra note 70, at 1937-46, 1988-92.

73 Rogers v. Grimaldi, 875 F.2d 994, 997-98 (2d Cir. 1989) (internal quotations and citations omitted); Rothman, supra note 70, at 1991. 
are not likely to signal sponsorship or source, and therefore should not give rise to an infringement claim. For example, the fact that a character has a Louis Vuitton bag (or a knock-off version of one) in a scene in a movie should not be an actionable infringement of any Louis Vuitton mark because no viewer would think the bag was there to indicate source, sponsorship, or affiliation by that company. ${ }^{74}$

\section{Statutory Exemptions from Dilution Claims}

In addition to providing for nominative and descriptive fair use defenses, the Lanham Act's dilution provision also contains specific exemptions for uses of marks in “news reporting and news commentary,” and for “[a]ny noncommercial use of a mark."75 Although the exemption for news is relatively straightforward, it is not clear exactly what is meant by a "noncommercial use" of a mark. ${ }^{76}$ The statute does not define the term. An accompanying congressional report to the Federal Trademark Dilution Act of 1995 suggests that the term means not "commercial speech," and "expressly incorporates the concept of 'commercial’ speech from the ‘commercial speech' doctrine, and proscribes dilution actions that seek to enjoin use of famous marks in 'non-commercial' uses (such as consumer product reviews)."77 The report also indicates that Congress wanted to exempt news reporting from liability for dilution, and perhaps exempt media more

${ }^{74}$ Louis Vuitton Malletier S.A. v. Warner Bros. Entm't Inc., 868 F. Supp. 2d 172, 177-84 (S.D.N.Y. 2012). This should be true even if some film studios routinely license trademarked products that appear in movies. See Jennifer E. Rothman, The Questionable Use of Custom in Intellectual Property, 93 VA. L. REV. 1899, 1912-16 (2007).

${ }^{75}$ Lanham Act § 43(c)(3), 15 U.S.C. § 1125(c)(3) (2012).

${ }^{76}$ Rothman, supra note 70 , at $1942-44$.

${ }^{77}$ H.R. REP. No. 104-374, at 8 (1995), reprinted in 1996 U.S.C.C.A.N. 1029, 1035. 
broadly (such as entertainment companies) ${ }^{78}$ Given that both news and the entertainment industry are most often for-profit enterprises, this goal can make sense only if the language is interpreted as exempting uses that are not commercial speech. This interpretation has been the one followed by most (though not all) courts. ${ }^{79}$

\section{Independent First Amendment Review}

With the exception of the Rogers test, which is understood as a particular analysis applying the First Amendment, the other speech-protective doctrines discussed in this Chapter are internal to trademark law. Other than the Rogers test, courts usually do not engage in additional independent First Amendment review in trademark cases. Even though intellectual property laws limit speech and do so on the basis of the content of that speech-something that is usually disfavored and presumptively unconstitutionalintellectual property laws have not been subject to the same level of scrutiny as other laws. $^{80}$

${ }^{78}$ Id.; see also 141 Cong. REC. H14317-01 (daily ed. Dec. 12, 1995) (statement of Rep. Moorhead).

${ }^{79}$ See, e.g., Radiance Found., Inc. v. N.A.A.C.P., 786 F.3d 316, 323-24 (4th Cir. 2015); Mattel, Inc. v. MCA Records Inc., 296 F.3d 894, 904-07 (9th Cir. 2002); but see Hershey Co. v. Friends of Steve Hershey, No. CIV. WDQ-14-1825, 2015 WL 795841, at *5-6 (D. Md. Feb. 24, 2015); Kraft Foods Holdings, Inc. v. Helm, 205 F. Supp. 2d 942, 952-55 (N.D. Ill. 2002); Films of Distinction, Inc. v. Allegro Film Prods., Inc., 12 F. Supp. 2d 1068, 1078-79 (C.D. Cal. 1998). Some state dilution claims also have been allowed in the context of noncommercial speech. See, e.g., Anheuser-Busch, Inc. v. Balducci Publ'ns, 28 F.3d 769, 777-78 (8th Cir. 1994). For further discussion of this issue see Rothman, supra note 70, at 1947-78; see also Lee Ann W. Lockridge, When is a Use in Commerce a Noncommercial Use?, 37 FLA. ST. U. L. REV. 337, 338 (2010).

${ }^{80}$ Reed v. Town of Gilbert, 135 S. Ct. 2218, 2226 (2015) (indicating that “[c]ontent-based laws . . . are presumptively unconstitutional and may be justified only if the government proves that they are narrowly tailored to serve compelling state interests”); see also ROTHMAN, supra note 62, at 143-45; Jennifer E. Rothman, The Right of Publicity's Intellectual Property Turn, 42 COLUMBIA J. L. \& ARTS 277, 312-14 (2019). 
In the context of copyright law, for example, the Supreme Court has suggested that the First Amendment will rarely (if ever) apply independently as a defense to copyright infringement claims because of copyright's internal speech restrictions, including its fair use defense and its exclusion of ideas and facts. ${ }^{81}$ This analysis suggests that courts might find trademark's internal limits on scope, combined with its fair use and other defenses adequately speech protective, without need for further First Amendment analysis. ${ }^{82}$ Even if courts can consider independent First Amendment analysis in trademark cases, they may rarely do so-preferring to apply defenses internal to trademark law under the doctrine of constitutional avoidance. ${ }^{83}$ To the extent that courts do consider First Amendment defenses, such defenses will likely be less successful in the context of uses in commercial speech. If the commercial speech at issue is false or misleading, then there is no First Amendment protection available. ${ }^{84}$

Despite these hurdles to First Amendment review in trademark cases, two recent decisions have raised the possibility that the First Amendment may start to play a bigger role. In Matal v. Tam, the Supreme Court struck down the Lanham Act’s prohibition on the registration of marks that may "disparage ... or bring ... into contempt or disrepute" "persons, living or dead, institutions, beliefs, or national symbols." ${ }^{\text {85 }}$ The Court held that

${ }^{81}$ Eldred v. Ashcroft, 537 U.S. 186, 218-21 (2003); see also Rothman, supra note 62, at 143-45; Jennifer E. Rothman, Liberating Copyright: Thinking Beyond Free Speech, 95 CORNELL L. REV. 463, 47692 (2010).

${ }^{82}$ See, e.g., Westchester Media v. PRL USA Holdings, Inc., 214 F.3d 658, 672 (5th Cir. 2000); Mutual of Omaha Ins. Co. v. Novak, 836 F.2d 397, 402 (8th Cir. 1987); cf. Anheuser-Busch, 28 F.3d at 775-78; Hershey Co. v. Friends of Steve Hershey, 33 F. Supp. 3d 588, 594-95 (D. Md. 2014).

${ }^{83}$ Leval, supra note 6, at 209.

${ }^{84}$ See Central Hudson Gas \& Elec. v. Pub. Serv. Comm’n, 447 U.S. 557, 563 (1980).

${ }^{85}$ Matal v. Tam, 137 S. Ct. 1744 (2017); see also 15 U.S.C. § 1052(a) (Lanham Act § 2(a)). 
the provision violated the First Amendment because it is a content-based speech restriction that discriminates on the basis of the speaker's viewpoint. Tam involved the U.S. Patent and Trademark Office’s (PTO’s) refusal to register the mark, THE SLANTS, for a rock band with Asian-American members who sought to reclaim the racial slur and defuse its negative connotations. The Supreme Court held that the PTO could not refuse to register negative terms for Asian people, while registering positive ones. ${ }^{86}$

On the basis of Tam, the Federal Circuit in In re Brunetti struck down a similar provision barring the registration of "immoral . . . or scandalous matter." The appellate court held that the PTO's refusal to register the term "FUCT" for apparel was unconstitutional even if viewpoint neutral. In reviewing this decision, the Supreme Court in Iancu $v$. Brunetti agreed that the bar was facially unconstitutional, but on a different basis - that it too discriminated on the basis of viewpoint, the same basis for the Court's holding in Tam. ${ }^{87}$ The Court held that the immoral and scandalous bar was impermissible because the provision "permits registration of marks that champion society's sense of rectitude and morality, but not marks that denigrate those concepts.” For example, "the PTO has refused to register marks communicating ‘immoral or scandalous’ views about (among other things) drug use, religion, and terrorism," but has "approved marks expressing more accepted views on the same topics.”88

Although a majority of the Court struck down the bar as facially unconstitutional, four justices suggested that a narrower bar on the registration of marks-limited to those

\footnotetext{
${ }^{86}$ Tam, 137 S. Ct. at $1747,1751$.

${ }^{87}$ Iancu v. Brunetti, 139 S. Ct. 2294 (2019); In re Brunetti, 877 F.3d 1330 (Fed. Cir. 2017).

${ }^{88}$ Brunetti, 139 S. Ct. at 2300.
} 
that are obscene, profane, or vulgar-could be constitutional. The majority did not opine on the constitutionality of such a provision, but it is possible that if Congress were to pass a more limited ban on the registration of these types of marks, it might survive constitutional review. ${ }^{89}$

It would be a mistake to think that Tam and Brunetti set the stage for a host of other challenges to the underlying constitutionality of trademark laws, or for increased First Amendment review in infringement and dilution claims. Tam and Brunetti both involved challenges to the denial of the benefits that registration provides to markholders, rather than challenges to the enforcement of markholders' rights. This makes these precedents less likely to be influential when asserted by defendants.

Although Tam and Brunetti are not likely to produce a massive shift in infringement and false endorsement analysis, they might fuel challenges to dilution claims, particularly viewpoint-based determinations of tarnishment. Some scholars even before these cases questioned the constitutionality of dilution laws because dilution claims do not require a showing that consumers are likely to be confused. ${ }^{90}$ Several Supreme Court decisions, however, suggest that dilution laws are likely to withstand a direct constitutional challenge even after Tam and Brunetti. Although the Supreme Court's 2012 decision in United States v. Alvarez struck down as unconstitutional the Stolen Valor Act, a law that made it a crime to falsely claim to have received a military

${ }^{89}$ Id. at 2301-02; id. at 2303 (Alito, J., concurring); id. at 2303-04 (Roberts, J., concurring in part); id. at 2304, 2306-08 (Breyer, J., concurring in part); id. at 2308-19 (Sotomayor, J., concurring in part).

${ }^{90}$ See, e.g., Eugene Volokh, Freedom of Speech and Intellectual Property: Some Thoughts after Eldred, 44 Liquormart, and Bartnicki, 40 Hous. L. REV. 697, 732- 39 (2003); see also Lisa P. Ramsey, Free Speech Challenges to Trademark Law after Matal v. Tam, 56 Hous. L. REV. 401 (2018). 
or Congressional Medal of Honor, a majority of justices in the case concluded that false speech could be penalized under some circumstances. ${ }^{91}$ And of particular relevance, both the concurrence and dissent pointed to trademark law as an example of a constitutional law that can restrict speech even when it is not false, but instead is only misleading or merely diluting. ${ }^{92}$

Further support for the broad constitutionality of dilution law is the Supreme Court's decision in San Francisco Arts \& Athletics v. U.S. Olympic Committee (SFAA). This 1987 case involved the application of a quasi-trademark statute that prohibited the use of the word "Olympics" and related marks without the authorization of the United States Olympic Committee (USOC). The Court held the statute constitutional even when applied to uses that were not confusing and that were not commercial speech, such as sporting events and theatrical works:

The mere fact that the SFAA claims an expressive, as opposed to a purely commercial, purpose does not give it a First Amendment right to 'appropriat[e] to itself the harvest of those who have sown.' The USOC's right to prohibit use of the word 'Olympic' in the promotion of athletic events is at the core of its legitimate property right. ${ }^{93}$

There is much to criticize in the Supreme Court's analysis in SFAA, and its unconvincing claim that there are adequate alternatives to the use of the word

${ }^{91}$ United States v. Alvarez, 567 U.S. 709, 721 (2012).

${ }^{92}$ Id. at 729-37 (Breyer, J., concurring); Id. at 738-53 (Alito, J., dissenting); see also Brunetti, 139 at 2305 (Breyer, J., concurring in part).

93 S.F. Arts \& Athletics, Inc. v. U.S. Olympic Comm., 483 U.S. 522, 525, 541 (1987) (quoting Int'l News Serv. v. Associated Press, 248 U.S. 215, 239-40 (1918)) (alteration in original); see also 36 U.S.C. § 220506 (2012) (granting by statute exclusive right to use the word "Olympic” and other related terms). 
"Olympics." The "Gay Olympics"—the use SFAA wanted to make—has a very different meaning from the "Gay Games," and in other contexts First Amendment analysis has held that such differences matter; for example, that "Fuck the Draft" is not the same as "Stop the Draft." ${ }^{94}$ Yet, the SFAA decision remains good law, and continues to be cited favorably by the Court. ${ }^{95}$

Despite the likely constitutionality of dilution law generally, the decisions in Tam and Brunetti suggest that the First Amendment may come into play if trademark laws are being applied in ways that discriminate on the basis of a speaker's viewpoint, or if they rest solely on causing offense. Some dilution claims based on tarnishment might therefore be ruled unconstitutional. In particular, the frequent conclusion that associations with sex presumptively tarnish a mark are constitutionally suspect after Tam and Brunetti. ${ }^{96}$

The Sixth Circuit's decision in V Secret Catalogue, Inc. v. Moseley seems unsupportable in light of these Supreme Court decisions. ${ }^{97}$ In V Secret, Victor Moseley, the defendant, ran an adult sex-themed shop that he named "Victor's Little Secret." The

${ }^{94}$ Cohen v. California, 403 U.S. 15 (1971); Dreyfuss, supra note 4, at 398-99, 410-21; Rothman, supra note 81, at 489; but see Iancu v. Brunetti, 139 S. Ct. 2294, 2314-15 (2019) (Sotomayor, J., concurring in part) (distinguishing Cohen on the grounds that it was a criminal case).

${ }^{95}$ See, e.g., Matal v. Tam, 137 S. Ct. 1744, 1752 (2017); Alvarez, 567 U.S. at 723, 736 (Breyer, J., concurring); Eldred v. Ashcroft, 537 U.S. 186, 221 (2003).

${ }^{96}$ For a discussion of such sex exceptionalism in IP cases, see Jennifer E. Rothman, Sex Exceptionalism in Intellectual Property, 23 StAN. L. \& POL’Y REV. 119 (2012).

${ }^{97}$ V. Secret Catalogue, Inc. v. Moseley, 605 F.3d 382 (6th Cir. 2010). The case was resurrected after a prior Supreme Court decision had thrown out Victoria's Secret's dilution claim on the basis that there was no evidence of actual dilution. After the decision, Congress amended the dilution provision to allow for liability on the basis of a likelihood of dilution, enabling the claim to proceed. See Moseley v. V. Secret Catalogue, Inc., 537 U.S. 418, 432-34 (2003), abrogated by Congress in the Trademark Dilution Revision Act of 2006 (codified at Lanham Act § 43(c)(1), 15 U.S.C. § 1125(c)(1) (2012)). 
store sold lingerie and sex toys, among other items. The plaintiff, owner of the famous Victoria’s Secret stores and marks, sued, contending that Moseley's use caused dilution by tarnishment. The Sixth Circuit held that the use of a similar mark to that of Victoria's Secret's—in the context of a "sex related product"—created a "rebuttable presumption" that it was tarnishing, a seemingly insurmountable hurdle for any defendant. ${ }^{98}$ This viewpoint-based conclusion (anti-sex) should not survive First Amendment review after Tam and Brunetti. The Sixth Circuit's conclusion that the use tarnished the famous lingerie chain's VICTORIA'S SECRET mark by associating it with sex was particularly absurd given the company's longstanding advertising campaigns that explicitly use the term "sexy" and show models in suggestive poses wearing only lingerie to promote sales of lingerie (which itself could be considered sex-themed). ${ }^{99}$ By holding that Moseley's use was tarnishing in this context, the Sixth Circuit weighed in not only on what it thought was broadly tarnishing-references to sex-but also expressed a view about what vision of sex is a good one. This conclusion is not constitutionally sound after Tam and Brunetti. ${ }^{100}$

\section{Conclusion}

The defenses highlighted in this Chapter provide a powerful antidote to the potential for trademark and related laws to shut down speech and unduly limit

\footnotetext{
${ }^{98}$ V. Secret, 605 F.3d. at 384-85, 388.

99 See id. at 391 (Moore, J., dissenting); Victoria's Secret “Very Sexy 2013” Campaign, HYPEBEAST (Apr. 16, 2013), https://hypebeast.com/2013/4/victorias-secret-very-sexy-2013-campaigndirected-by-michael-bay.

${ }^{100}$ But see Iancu v. Brunetti, 139 S.Ct. 2294, 2313 (2019) (Sotomayor, J., concurring in part) (discussing that regulations on pornography are constitutional even though they may regulate the expression of views on “sexual liberation”).
} 
competition. Defendants are more likely to prevail when they can make a convincing case that their uses further free speech values. When defendants use others' marks (or something similar) to provide consumers with information, or to express themselves particularly in a non-advertising, artistic context, the uses will likely be protected by one of the defenses discussed.

In contrast, when courts think the uses are exploiting a plaintiff's mark, trade dress, or identity for financial benefit without a corresponding free speech benefit of providing commentary, comparison, or original expression, these defenses are likely to fail. This evaluation will turn in part on the necessity and reasonableness of the uses given the articulated speech objectives, and the demands of competing in the marketplace. Speech-related defenses are less likely to prevail if a use conveys false or misleading information because such uses deceive rather than inform the public. Similarly, when a use provides no additional commentary on the underlying mark, or original expression, courts will often view the use as a subterfuge for the defendant's exploitation of another's goodwill, rather than as a use in furtherance of free expression.

The First Amendment and its speech-protective penumbras incorporated into trademark law provide latitude to use others' marks both in commercial and noncommercial speech, but this protection is not without limits. When a use exceeds what is appropriate under the circumstances, and is perceived as primarily profiting from another's goodwill without a corresponding speech benefit, these defenses are unlikely to provide protective shade. 